\title{
KINERJA INSTALASI FARMASI RUMAH SAKIT X PURWOKERTO DITINJAU DARI PERSPEKTIF PROSES BISNIS INTERNAL BALANCED SCORECARD "AVERAGE DISPENSARY TIME DAN WAKTU PEMBERIAN INFORMASI OBAT"
}

\author{
Fithria Dyah Ayu $\mathbf{S}^{{ }^{\star}}$., Satibi ${ }^{2}$, Achmad Fudholi ${ }^{2}$ \\ ${ }^{1}$ Program Studi Profesi Apoteker Universitas Islam Indonesia \\ ${ }^{2}$ Fakultas Farmasi Universitas Gadjah Mada \\ *email: fithria.ayu@gmail.com
}

\begin{abstract}
ABSTRAK
IFRS (Instalasi Farmasi Rumah Sakit) X Purwokerto adalah salah satu rumah sakit milik pemerintah yang bergerak pada pelayanan publik. IFRS $X$ sebagai salah satu organisasi yang memasuki lingkungan industri kesehatan yang kompetitif harus dapat meningkatkan kinerja dan memberikan pelayanan terintegrasi secara lebih efektif, efisien, dan inovatif. Penelitian ini bertujuan untuk mengetahui proses bisnis internal IFRS $X$ berdasarkan perspektif balanced scorecard, meliputi ratarata dispensing time, dan rata-rata waktu pemberian informasi obat. Desain penelitian ini adalah cross sectional. Data kuantitatif didapatkan dari lembar observasi pada resep untuk rata-rata dispensing time.
\end{abstract}

Kata kunci : IFRS X Purwokerto, proses bisnis internal, rata-rata dispensing time, rata-rata waktu pemberian informasi obat.

\section{ABSTRACT}

IFRS $X$ Purwokerto is one of government's hospital as a public services. Organization such as IFRS $X$ in todays dynamic healthcare system required to improve their performance and deliver an integrated care that means to be effectively, efficiently, and be innovative. This article presents an investigation in internal processes IFRS $X$ based on balanced scorecard perspective, thats are average dispensary time and average drug information time. The research design was cross sectional study. Quantitative data for average dispensary time were obtained from observation with sheet data collectors on the receipts document, while for average drug information time were obtained from observation the timing of drug information by pharmacy department staff to the patients. Qualitative data were obtained from unstructured interview with the pharmacy department staff. Quantitative data were analyzed as a mean of time of dispensing time, and qualitative data was descriptive analyzed. Result shown the average dispensary time in Satelit Farmasi Rawat Jalan Umum for non coumpounding prescription was 27 minutes and 10 seconds, compounding prescription was 43 minutes 25 seconds, while in Satelit Farmasi Rawat Jalan ASKES average dispensary time for non compounding prescription was 20 minutes 2 seconds, and for compounding prescription was 29 minutes. The average drug information time was 12,44 seconds, include the rules and how to use the drug, the duration of treatment, and the efficacy of drug.

Keywords: internal processess perspective, IFRS $X$ Purwokerto, average dispensary time, average drug information 


\section{PENDAHULUAN}

Lingkungan industri jasa pelayanan kesehatan pada era sekarang memasuki industri yang sangat kompetitif, dan salah satu keunggulan bersaing di antara para penyedia jasa pelayanan kesehatan adalah service excellence (Ford R.C., et al., 2006). Berdasarkan Surat Keputusan Direktur Nomor 800/766/III/2000 IFRS X Purwokerto sebagai salah satu unit penyedia layanan kesehatan memiliki misi antara lain menyelenggarakan pengelolaan perbekalan farmasi secara efisien, efektif, sehingga memuaskan semua pihak, serta menyelenggarakan pelayanan kefarmasian dalam penggunaan sediaan farmasi dengan menghormati hak pasien sebagai salah satu service excellence. Dalam lingkungan industri pelayanan kesehatan yang sangat dinamis, organisasi seperti rumah sakit membutuhkan peningkatan kinerja untuk stakeholder dan menghantarkan pelayanan secara terintegrasi dalam arti secara efektif, inovatif, dan efisien (Lupi S., et al, 2011). Dalam rangka mengukur pencapaian misi IFRS $X$ Purwokerto, maka dilakukan pengukuran kinerja dalam perspektif proses bisnis internal dari perspektif balanced scorecard. Aplikasi analisis dari perspektif proses bisnis internal balanced scorecard dalam industri pelayanan kesehatan harus dimodifikasi dengan melaporkan indikator peningkatan kualitas yang terus menerus dan desain pelayanan yang terintegrasi (Lupi S., et al, 2011). Balanced scorecard adalah salah satu alat manajemen yang pada awalnya diaplikasikan pada sektor swasta oleh Kaplan dan Norton pada tahun 1992 (Kaplan dan Norton, 1992). Penggunaan balanced scorecard dalam industri pelayanan kesehatan memungkinkan untuk mengembangkan indikator kinerja yang lebih komprehensif (Lupi S., et al, 2001). Pada ranah kompetisi berbasis pengetahuan, kemampuan organisasi untuk mengembangkan, memelihara, dan menggerakan aset tidak berwujud mereka sangat penting untuk keberhasilan (Kaplan \& Norton, 2001). Balanced scorecard memungkinkan manajemen untuk melihat bisnis dari empat perspektif penting dan untuk menerima jawaban atas empat pertanyaan penting (Kaplan \& Norton, 1992).

1. Bagaimana pelanggan melihat (menilai) kita? (Customer perspective)

2. Kita harus unggul dalam apa? (Internal perspective)

3. Dapatkah kita terus meningkatkan dan menciptakan nilai? (Innovation and learning perspective)

4. Bagaimana kita melihat pada para pemegang saham? (Financial perspective)

Organisasi pada beberapa waktu menghadapi kesulitan, dan manajemen perlu menerapkan beberapa bentuk sistem manajemen kinerja untuk meningkatkan efisiensi dan memotivasi karyawan untuk bisa sukses (Gustafsson K., et al, 2009). "Perspektif proses bisnis internal memiliki 2 (dua) komponen penting dari strategi organisasi, yaitu (1) mereka menghasilkan dan menghantarkan nilai terdepan bagi pelanggan, (2) mereka memperbaiki proses dan mengurangi biaya untuk komponen produktivitas dalam perspektif keuangan (Kaplan \& Norton, 2004, pg. 98). Pengukuran perspektif proses bisnis internal 
dalam balanced scorecard harus berasal dari proses bisnis yang memiliki dampak terbesar, seperti siklus waktu, kualitas, keterampilan karyawan, dan produktivitas (Kaplan \& Norton 1992, pg. 132). Hal penting lain yang harus diperhatikan oleh organisasi adalah mengidentifikasi kompetensi inti yang mereka miliki, serta teknologi yang dibutuhkan untuk menjaga pangsa pasar mereka (Kaplan \& Norton 1992, pg. 132).

Salah satu pengukuran kinerja perspektif proses bisnis internal adalah pengukuran dispensing time dan waktu pemberian informasi obat. Dispensing merupakan kegiatan pelayanan yang dimulai dari tahap validasi, interpretasi, menyiapkan/meracik obat, memberikan label/etiket, penyerahan obat dengan pemberian informasi obat yang memadai disertai sitem dokumentasi (Depkes, 2004).

\section{METODE PENELITIAN}

Rancangan penelitian adalah cross sectional analytic, dengan pengambilan data kuantitatif dispensary time dan waktu pemberian informasi obat, dan data kualitatif. Pengambilan data kuantitatif dispensary time diperoleh dari observasi di lapangan pada pasien rawat jalan umum dan rawat jalan ASKES yang menebus resep di IFRS $X$ Purwokerto, dengan menggunakan Lembar Pengumpul Data yang berisi nomor resep, tanggal penerimaan resep, periode pengambilan data, yaitu periode I (jam 08.00-10.00 WIB) dan periode II (jam 10.00 - selesai), jenis resep (racikan/nonracikan), jenis kegiatan yang dilakukan dalam pelayanan resep, waktu yang diperlukan untuk masing-masing kegiatan dalam pelayanan resep, dan total waktu yang diperlukan untuk melakukan pelayanan resep. Teknik pengambilan sampel adalah dengan convenience sampling, dengan kriteria inklusi LPD terisi dengan lengkap oleh petugas. Analisa data dengan menghitung nilai rata-rata /average dispensary time resep pasien rawat jalan umum yang dibedakan atas resep racikan dan non racikan.

Pengambilan data kuantitatif waktu PIO (Pemberian Informasi Obat) dilakukan dengan observasi di lapangan terhadap waktu pemberian informasi obat oleh petugas farmasi pada saat penyerahan obat hingga berakhirnya informasi yang diberikan oleh petugas kepada pasien. Observasi dilakukan pada 100 subjek penelitian. Analisa data dengan menghitung rata-rata waktu pemberian informasi obat oleh petugas kepada pasien.

Pengambilan data kualitatif dengan wawancara tidak terstruktur kepada karyawan/petugas satelit farmasi rawat jalan umum dan ASKES. Hasil wawancara tidak terstruktur kemudian diolah dalam bentuk narasi/deskripsi.

\section{HASIL DAN PEMBAHASAN}

Pengukuran average dispensary time di instalasi farmasi rawat jalan Rumah Sakit X Purwokerto

Indikator pengukuran kinerja perspektif proses bisnis internal dari balanced scorecard dalam bidang jasa antara lain adalah waktu tunggu, yang dalam penelitian ini disebut sebagai average dispensary time. Indikator lainnya yang diukur dalam penelitian ini adalah waktu PIO (Pemberian Informasi Obat) oleh petugas farmasi kepada pasien. 
Pengukuran dispensing time dilakukan di instalasi farmasi rawat jalan RS $X$ Purwokerto, baik di satelit farmasi rawat jalan umum maupun satelit rawat jalan ASKES. Jumlah sampel penelitian untuk rawat jalan umum adalah sebanyak 142 pasien, dan untuk rawat jalan ASKES adalah sebanyak 222 pasien yang dibagi ke dalam resep racikan dan resep non racikan.

Tabel 1. Average Dispensary Time di Satelit Farmasi Rawat Jalan Umum RS X Purwokerto

\begin{tabular}{ccc}
\hline Keterangan & \multicolumn{2}{c}{ Waktu penyediaan obat (menit) } \\
\cline { 2 - 3 } & Non Racikan & Racikan \\
\hline Jumlah Sampel (lembar resep) & 101 & 41 \\
Rerata & 27 menit 50 detik & 43 menit 25 detik \\
Minimum & 10 menit & 16 menit \\
Maximum & 56 menit & 60 menit 14 detik \\
Standar Deviasi & 11 menit 12 detik & 14 menit 7 detik \\
\hline
\end{tabular}

Hasil pengukuran average dispensary time di satelit farmasi rawat jalan ASKES adalah sebagai berikut:

Tabel 2. Average Dispensary Time di Satelit Farmasi Rawat Jalan ASKES RS X Purwokerto

\begin{tabular}{ccc}
\hline Keterangan & \multicolumn{2}{c}{ Waktu penyediaan obat (menit) } \\
\cline { 2 - 3 } & Non Racikan & Racikan \\
\hline Jumlah Sampel (lembar resep) & 160 & 62 \\
Rerata & 20 menit 2 detik & 29 menit \\
Minimum & 5 menit & 6 menit \\
Maximum & 60 menit & 67 menit \\
Standar Deviasi & 10,79 & 14,05 \\
\hline
\end{tabular}

Pengukuran average dispensary time dilakukan sejak awal pasien menyerahkan resep hingga berakhir ketika pasien telah selesai memperoleh obat. Hasil pengukuran average dispensary time di satelit farmasi rawat jalan umum belum memenuhi standar yang telah ditetapkan oleh IFRS $X$ Purwokerto untuk dispensing time, yaitu untuk resep racikan 40 menit, dan untuk resep non racikan 20 menit, sedangkan untuk satelit farmasi rawat jalan ASKES telah memenuhi standar yang ditetapkan.

Data yang diperoleh dari satelit farmasi rawat jalan umum tahap yang paling lama adalah tahap entry data dan konfirmasi harga. Hasil wawancara tidak terstruktur dengan petugas/karyawan IFRS $X$ Purwokerto menyatakan bahwa hal tersebut dipengaruhi oleh perubahan SIM (Sistem Informasi Manajemen) yang baru, sehingga petugas/karyawan memerlukan adaptasi dan pelatihan lagi, selain dari sisi ketidaksiapan SDM (Sumber Daya Manusia) terhadap perubahan SIM, juga dipengaruhi oleh SIM yang kurang mengakomodasi kebutuhan pelayanan, seperti kurang up date terhadap database harga obat-obatan dan ketersediaan obat-obatan di IFRS $X$ Purwokerto. Hal yang juga berpengaruh dalam lama pelayanan adalah kekurangan tenaga pelayanan. 
Data yang didapatkan dari satelit farmasi rawat jalan ASKES tahapan paling lama adalah pada saat penyiapan obat. Hasil wawancara tidak terstruktur dengan petugas/karyawan IFRS $X$ Purwokerto menyatakan bahwa hal tersebut disebabkan oleh jumlah SDM yang terbatas, tingkat kekosongan obat di satelit farmasi rawat jalan ASKES yang tinggi, SIM yang kurang mendukung untuk mempercepat pelayanan, SDM yang kurang terlatih, dan tempat/ruangan penyiapan obat dan penyimpanan obat yang terbatas (sempit).

$$
\text { Pihak IFRS } X \text { Purwokerto }
$$

sebaiknya mengkomunikasikan terlebih dahulu dengan seluruh SDM yang berhubungan dengan pelayanan terkait dengan implementasi SIM yang baru, dan mengadakan pelatihan.

\section{Pengukuran waktu pemberian infornasi obat}

Pemberian informasi obat oleh karyawan IFRS $X$ kepada pasien pada saat penyerahan obat berupa cara dan aturan pakai obat, jangka waktu pengobatan, serta khasiat obat, sedangkan komponen informasi yang tidak diberikan berdasarkan Standar Pelayanan Kefarmasian di Apotek berdasarkan KMK (Keputusan Menteri Kesehatan) Nomor 1027/Menkes/SK/IX/2004 adalah cara penyimpanan obat, dan aktivitas, serta makanan dan minuman yang harus dihindari selama terapi. Hasil penelitian menunjukkan rata-rata waktu pemberian informasi obat di IFRS $X$ Purwokerto adalah 12,44 detik. Pemberian informasi obat kepada pasien penting untuk dilaksanakan, walaupun di dalam obat telah diberikan label aturan pakai obat. Hal tersebut berdasarkan hasil penelitian dari
Shrank dan Avorn pada tahun 2007 menyebutkan bahwa pemberian label pada obat yang tidak jelas memiliki pengaruh besar untuk menimbulkan medication error, oleh sebab itu komunikasi aktif dari staf farmasi sangat dibutuhkan untuk mengedukasi pasien. Berdasarkan panduan dari American College of Preventive Medicine, 2011 menyebutkan bahwa dalam rangka meningkatkan kepatuhan pasien dalam menyelesaikan pengobatannya, maka dibutuhkan peran aktif dari healthcare provider termasuk di dalamnya adalah apoteker untuk memberikan informasi mengenai pengobatan dengan menggunakan intervensi SIMPLE, yaitu Simplify the regimen, Impart Knowledge, Modify patient beliefs and human behaviour, Provide communication and trust, Leave the bias, dan Evaluate adherence. Pemberian informasi obat juga harus menggunakan kalimat yang sederhana dan mudah dipahami.

\section{KESIMPULAN}

Average dispensary time untuk resep di satelit farmasi rawat jalan umum untuk resep nonracikan adalah 27 menit 50 detik, dan untuk resep racikan adalah 43 menit 25 detik, sedangkan average dispensary time di satelit farmasi ASKES untuk resep nonracikan adalah 20 menit 2 detik, sedangkan untuk resep racikan adalah 29 menit. Waktu pemberian informasi obat rata-rata adalah 12,44 detik, dengan komponen informasi berupa cara dan aturan pakai obat, jangka waktu pengobatan, serta khasiat obat. Hal tersebut menunjukkan masih perlunya perbaikan dalam proses bisnis internal di IFRS $X$ Purwokerto baik 
dengan penggunaan teknologi, misal dengan menggunakan SIM (Sistem Informasi Manajemen) yang lebih baik dan terintegrasi, serta penekanan kembali filosofi pharmaceutical care kepada staf farmasi.

\section{DAFTAR PUSTAKA}

American College of Preventive Medicine, 2011, Medication Adherence Time Tool: Improving Health Outcomes "A Resources from The American College of Preventive Medicine", Washington, USA

Ford R.C., Sivo SA., Fottler MD., Dickson D., Bradley K., Johnson L., 2006, Aligning Internal Organizational Factors with $A$ Service Excellence Mission: An Explaratory Investigation in Healthcare., Health Care Manage Rev, diakses dari www.ncbi.nlm.nih pada 10 Mei 2014

Gustafsson K., Schold C., Sihvo C., Summit S, 2009, Application of the Balanced Scorecard in the Healthcare Department within Jonkoping County Council, Thesis, diakses pada $10 \mathrm{Mei}$ 2014

Kaplan, R., Norton, D., 2001, The Strategy Focused Organization, Harvard Business School Press, Boston

Kaplan, R., \& Norton, D., 1992, The balanced scorecard - Measures that drive performance, Harvard Business Review on Corporate Performance, Harvard Business School Press, Boston

Kaplan, R., \& Norton, D., 2004, Strategy Maps, converting intangible assets into tangible outcomes, Harvard Business School Press, Boston

Lupi S., Verzola A., Carandina G., Salani M., Antoniolli P., Gregorio P., 2011, Multidimensional Evaluation of Performance with Experimental Application of Balanced Scorecard: A Two Years Experience, Cost Effectiveness and Resources Allocation, diakses pada 10 Mei 2014

Shrank, W.H., Avorn., J., 2007, Educating Patients About Their Medications: The Potential And Limitation of Written Drug Information, Health Affairs 26, No 3, p.731-740 